\title{
MEMBANGUN PARADIGMA BARU HUKUM PERUSAHAAN DAN ETIKA KEWIRAUSAHAAN
}

Oleh:

\author{
Wirazilmustaan, S.H., M.H. ${ }^{*}$ dan Abdul Rasyid Saliman bin Mohd. Arsyad Midin ${ }^{* *}$ \\ Email:wira.aan@gmail.com
}

Abstract

Curriculum of corporate law must be prepared to enter into the world of the industry with a very characteristic and distinctive, and the corporate law is not separated from the external business culture conditions develop. This means, the conditions of the external culture assumed already embedded in advance within the students, before they work in a company and then drift in the culture of the company. Because of its implication, build a new paradigm of curriculum into an absolute obligation to be met by faculty of law at this time. Construct curriculum based corporate law building the entrepreneurial spirit in faculty of law is the solution. The results showed that the revitalization of the new paradigm in developing corporate law should be immediately done. Where in the era of free market today many businessmen doing business without an understanding of corporate law and a strong corporate culture. The implications of this, the theories of corporate law, in the curriculum of lectures, also great for hindsight.

Keywords : Paradigma baru, hukum perusahaan, kurikulum hukum perusahaan, budaya perusahaan, etika kewirausahaan

\section{A. PENDAHULUAN}

Hukum perusahaan merupakan kumpulan aturan-aturan tertulis maupun tidak tertulis yang mengatur bentuk-bentuk organisasi bisnis yang mengatur hak dan kewajiban yang timbul dari perjanjian-perjanjian dalam praktik bisnis. ${ }^{1}$ Organisasi bisnis tersebut akan mengkodifikasi

*Dosen Tetap Fakultas Hukum Universitas Bangka Belitung.

**Dosen Tetap Fakultas Hukum Universitas Bangka Belitung.

${ }^{1}$ Rasyid Saliman, Abdul, Hukum Bisnis untuk Perusahaan cetakan ke 11, Prenada Media, Jakarta, 2017. hlm.8. harapan dari etika dalam melaksanakan kegiatan bisnis dan kewirausahaan. Meskipun disadari tidak semua harapan etika tersebut dapat dipenuhi oleh hukum perusahaan. Norma etika memang bersifat dinamis, tetapi begitu ia dituangkan dalam ketentuan hukum perusahaan sifat dinamisnya menjadi berkurang/ bahkan mungkin menjadi statis. Maka di sini hukum tentunya harus memperhatikan pula apabila adanya perubahan-perubahan. 
Disinilah pentingnya pemahaman etika bagi pelaku bisnis dalam membaca setiap perkembangan organisasi bisnis itu.

Etika kewirausahaan merupakan kode etik yang diberlakukan untuk profesi kewirausahaan dalam suatu organisasi bisnis dalam konteks menjalankan setiap aturan menurut hukum perusahaan itu. Kode etik berlaku untuk suatu profesi kewirausahaan yang bertindak secara profesional.

Karena itu pelaku bisnis mempunyai tanggung jawab khusus. Melalui kode etik kepercayaan masyarakat akan suatu profesi dapat diperkuat, etika kewirausahaan merupakan dasar moral yaitu nilainilai tentang apa yang baik dan apa yang buruk, dan berkaitan dengan hak dan kewajiban setiap pelaku usaha. Dapat berfungsi sebagai pedoman perilaku, sikap atau tindakan yang diterima dan diakui sehubungan dengan kegiatan manusia atau kelompok bisnis.

Dengan ini etika kewirausahaan merupakan proses pembelajaran mengenai benar dan salah dan kemudian melakukan hal yang benar dan ini merupakan persoalan pendidikan, memberikan contoh yang benar dan pelayanan untuk mempraktikkan perilaku moral dengan dialog yang jujur. Bahkan etika kewirausahaan dipandang sebagai ilmu tentang berperilaku mencakup aturan dasar yang dianut dalam hidup dan kehidupan supaya tindakan punya nilai moral, tindakan ini harus dijalankan berdasarkan kewajiban.

Nilai moral dari tindakan ini tidak tergantung pada tercapainya tujuan dari tindakan itu melainkan tergantung pada kemauan baik yang mendorong seseorang untuk melakukan tindakan itu, berarti kalaupun tujuan tidak tercapai, tindakan itu sudah dinilai baik, sebagai konsekuensi dari kedua prinsip ini, kewajiban adalah hal yang niscaya dari tindakan yang dilakukan berdasarkan sikap hormat pada hukum perusahaan dan nilai moral secara universal.

Etika dipandang sebagai state of the art hukum yaitu dimana pedoman perilaku yang ada saat ini ditafsirkan ke dalam hukum perusahaan dan digunakan dan sejalan dengan etika kewirausahaan sebagai pedoman selanjutnya untuk masa yang akan datang.

Pelaku kewirausahaan atau bisnis mempunyai peranan dalam menumbuhkan bisnis yang 
berbudaya, bermoral dan taat/sadar hukum. Kesadaran hukum harus dapat merata diantara pelaku bisnis, para eksekutif. Para birokrat, yang didukung pula oleh faktor lingkungan yang sehat dalam berbisnis, sehingga budaya bisnis yang baik, sehat tetap terjaga dan terpelihara.

Budaya bisnis yang kuat akan melahirkan budaya perusahaan, budaya perusahaan dalam perspektif manajemen hingga kini masih diyakini sebagai pola sikap, keyakinan, asumsi, dan harapan yang dimiliki bersama, yang mungkin tidak tertulis, namun membentuk cara bagaimana sumber daya manusia di dalam suatu perusahaan bertindak dan berinteraksi dukungmendukung demi menyukseskan tujuan perusahaan.

Pembangunan karakter ini mengarah kepada kesejahteraan hidup, mengingat pola di dalam kehidupan industrial dewasa ini selalu mengarah pada tuntutan kompetensi pelaku bisnis berdasarkan pendidikan formalnya. Padahal, kewirausahaan mestinya tidak melihat kompetensi seseorang hanya berdasarkan pendidikan formalnya semata-mata, tetapi juga melihat semangat hidupnya, kemandiriannya, kepribadiannya, keluwesannya, dan kreativitasnya dalam menciptakan lapangan kerja bagi dirinya sendiri dan dalam rangka mengambil keputusan dalam rangka menangkap peluang bisnis.

Sejak munculnya istilah hukum perusahaan yang berusaha mengambil alih peranan hukum dagang. Hukum perusahaan sudah dijadikan materi kuliah wajib di beberapa perguruan tinggi yang terkesan berdiri sendiri berdampingan dan menggantikan hukum dagang walaupun secara substansi kedua istilah tersebut hampir tidak ada perbedaan, tetapi secara umum hukum perusahaan lebih diminati dan mudah dipahami bila dibandingkan dengan hukum dagang. Hukum dagang lebih banyak dipahami oleh mahasiswamahasiswa fakultas hukum, sedangkan hukum perusahaan (organisasi bisnis) merupakan materi kuliah yang selalu disajikan pada fakultas ekonomi sehingga wajar bila hukum perusahaan lebih banyak dikenal oleh mahasiswa-mahasiswa fakultas ekonomi. $^{2}$

\footnotetext{
${ }^{2}$ Mulhadi, Hukum Perusahaan, BentukBentuk Badan Usaha di Indonesia, Ghalia Indonesia. Bogor, 2010, hlm. 6.
} 
Sedangkan pola hidup yang hedonis-konsumerisme saat ini menyebabkan pelaku bisnis sangat sedikit yang mampu berwirausaha secara baik dan benar, dan akhirnya etika kewirausahaan masih menjadi wacana ketimbang praksis. Hal yang dilematis inilah yang harus terusmenerus dicarikan solusinya karena tidak sesuai lagi dengan perkembangan dalam dunia bisnis dan prinsip hukum perusahaan tersebut sudah tidak dapat lagi dipertahankan dalam situasi saat ini.

Berdasarkan uraian tersebut di atas, maka dapat dirumuskan pokok permasalahan, sebagai berikut:

1. Bagaimanakah upaya membangun paradigma baru hukum perusahaan dan etika kewirausahaan dalam konteks kekinian?

2. Apakah hukum perusahaan sudah dilaksanakan sesuai dengan prinsip etika kewirausahaan yang baik dan kendala-kendala apa saja yang dihadapi dalam membangun etika kewirausahaan tersebut?

\section{B. METODE PENELITIAN}

\section{Objek dan Lokasi Penelitian}

Objek penelitian adalah membangun paradigma baru, sedangkan subjek penelitian adalah hukum perusahaan dan etika kewirausahaan menurut peraturan perundang-undangan di Indonesia dengan tempat penelitian dilaksanakan di Indonesia.

\section{Tipe dan Pendekatan Penelitian}

Sebagai konsekuensi pemilihan topik permasalahan yang akan dikaji dalam penelitian yang objeknya membangun paradigma baru hukum perusahaan dan etika kewirausahaan yang dibatasi pada peraturan perundang-undangan di Indonesia, maka tipe penelitian yang digunakan adalah penelitian hukum normative, ${ }^{3}$ yakni penelitian yang difokuskan untuk mengkaji penerapan kaidahkaidah atau norma-norma dalam hukum positif. Dalam hubungan ini, digunakan logika induktif. Logika induktif digunakan untuk menarik kesimpulan dari hal-hal khusus yang bersifat individual menjadi hal yang bersifat umum. ${ }^{4}$ Dalam penelitian ini juga secara 
proporsional menggunakan tipe penelitian empirikal dalam rangka mengkaji penerapan kaidahkaidah hukum dalam kondisi yang nyata. Oleh karena itu, digunakan logika deduktif. Logika deduktif digunakan untuk menarik kesimpulan dari hal-hal yang bersifat umum menjadi hal yang bersifat khusus.

$\begin{array}{rrr}\text { Dalam } & \text { kaitannya } & \text { dengan } \\ \text { penelitian } & \text { normatif } & \text { disini }\end{array}$
digunakan beberapa pendekatan, yaitu pendekatan perundangundangan (statute approach). Pendekatan tersebut melakukan pengkajian peraturan perundangundangan yang berhubungan dengan tema sentral penelitian. Selain itu juga digunakan pendekatan perbandingan (comparative approach), dan pendekatan sejarah (historical approach) yang diperlukan guna memperjelas analisis ilmiah yang diperlukan dalam penelitian normatif.

\section{Prosedur Pengolahan Bahan}

\section{Hukum}

Untuk memperoleh bahan penelitian dilakukan dengan prosedur pengumpulan melalui dua cara, yakni: Pertama, studi kepustakaan, studi kepustakaan tidak saja terhadap bahan-bahan perundangan, penulis juga mencari bahan pada buku-buku, jurnal-jurnal, makalah-makalah, laporan-laporan, hasil penelitian, bahan-bahan yang diperoleh yang berhubungan dengan masalah membangun paradigma baru hukum perusahaan dan etika kewirausahaan serta menggali permasalahan-permasalahan yang timbul dalam penerapan UndangUndang atau peraturan yang memuat hukum perusahaan dan etika kewirausahaan, dan; Kedua, wawancara, dimana bahan hukum diperoleh dengan mewawancarai pihak terkait dengan topik yang diambil, seperti ketua jurusan di fakultas hukum.

Jenis bahan yang digunakan dalam penelitian ini, yakni; jenis bahan primer dan bahan sekunder. Jenis bahan primer, yakni jenis bahan yang di dapat berdasarkan hasil di lapangan dengan wawancara dan sifatnya sebagai pelengkap (komplementer), sedangkan jenis bahan sekunder merupakan jenis bahan yang di dapat bukan dari lapangan dan di dapat dalam bentuk tiga bahan hukum, yakni: 
a. Bahan hukum primer, yaitu bahan-bahan hukum perusahaan dan peraturan perundang-undangan yang berhubungan dengan etika kewirausahaan.

b. Bahan hukum sekunder, yaitu bahan hukum yang terdiri atas buku-buku teks (textbooks) yang ditulis para ahli hukum yang berpengaruh, jurnaljurnal hukum, pendapat para sarjana, kasus-kasus hukum, yurisprudensi, dan hasil-hasil simposium mutakhir yang berkaitan dengan topik penelitian.

c. Bahan-bahan tersier, yaitu bahan yang memberikan petunjuk maupun penjelasan terhadap bahan hukum primer dan sekunder, seperti; kamus, ensiklopedi dan lain-lain.

Setelah

pengumpulan bahan hukum primer, bahan hukum sekunder, dan bahan-bahan tersier dilakukan, kemudian bahan hukum tersebut diinventarisasi dan diklasifikasi dengan menyesuaikan dengan masalah yang dibahas. Bahan hukum yang berhubungan dengan masalah yang dibahas dipaparkan, disistematisasi, $\quad$ kemudian dianalisis untuk menginterpretasikan hukum yang berlaku.

\section{Pengolahan dan Analisis Bahan} Hukum

Adapun bahan-bahan hukum yang telah diperoleh dalam penelitian kepustakaan, aturan perundang-undangan, dan artikel dimaksud penulis uraikan dan hubungkan sedemikian rupa, sehingga disajikan dalam penulisan yang lebih sistematis untuk menjawab isu hukum yang telah dirumuskan dalam rumusan masalah. Bahwa cara pengolahan bahan hukum dilakukan secara induktif dan secara deduktif yakni menarik kesimpulan dari suatu permasalahan yang bersifat khusus terhadap permasalahan umum dan menarik kesimpulan dari suatu permasalahan yang bersifat umum terhadap permasalahan konkrit yang dihadapi. Selanjutnya bahan hukum yang ada dianalisis untuk melihat bentuk kurikulum hukum perusahaan dalam sistem peraturan perundang-undangan sehingga dapat membantu sebagai dasar acuan dan pertimbangan hukum yang berguna untuk 
pelaksanaan prinsip etika

kewirausahaan secara tepat.

\section{PEMBAHASAN}

\section{Paradigma Baru Hukum}

\section{Perusahaan}

Kondisi

lingkungan

masyarakat ekonomi ASEAN

pada saat ini dapat membawa

pelaku bisnis untuk masuk dalam

bisnis internasional dan

pengelolaan bisnis secara

profesional berdasarkan keahlian

dan ketrampilan khusus,

mempunyai komitmen moral yang tinggi, dan menjalankan usahanya berdasarkan

profesi/keahlian dan kurikulum hukum perusahaan yang harus disesuaikan.

Pada saat ini bentuk-bentuk perusahaan multinasional sudah merupakan kelaziman bila kita ingin berbisnis dengan pelaku bisnis internasional. Oleh karena itu, setidaknya dalam kurikulum hukum perusahaan di perguruan tinggi saat ini dapat menyesuaikan dengan penambahan materi-materi dan bentuk perusahaan multinasional tersebut.

Oleh karena itu, kurikulum hukum perusahaan di perguruan tinggi harus menyelaraskan diri dengan gaya manajemen perubahan yang terjadi dan berkembang tersebut. Dalam penegasan lain, semangat kapitalisme yang amat merasuki dunia pendidikan tinggi dewasa ini, menyebabkan mahasiswa hanya tumbuh sebagai makhluk industri, dan mereka sama sekali tidak bisa merasakan spirit pendidikan dengan kurikulum perubahan di dalam hukum perusahaan.

Andaipun ada, spirit itu hanya ditempelkan pada mata kuliah tertentu yang secara filosofis justru bertolak belakang dengan makna dan isi kurikulum sendiri. Sebagai catatan, di perguruan tinggi kita memang ada mata kuliah Hukum dan Etika Bisnis, Budaya Organisasi, dan Kewirausahaan, tetapi muatannya terlalu teoretis dan cenderung menggarisbawahi nilai-nilai kapitalisme.

Kurikulum hukum perusahaan harus dipersiapkan untuk masuk ke dunia industri dengan bercirikan dan berkarakter khas, dan hukum perusahaan ini tidak lepas dari kondisi budaya bisnis eksternal yang 
berkembang. Hal ini berarti, kondisi budaya eksternal diandaikan sudah tertanam terlebih dahulu di dalam diri mahasiswa, sebelum mereka ini bekerja di sebuah perusahaan dan kemudian hanyut di dalam budaya perusahaan itu. Sebab implikasinya, membangun paradigma baru kurikulum menjadi suatu kewajiban mutlak yang harus dipenuhi oeh fakultas hukum saat ini.

Selain itu di dalam konteks hukum perusahaan, pembahasan budaya perusahaan merupakan bagian terpenting dalam mengembangkan pemahaman baru tentang eksistensi organisasi bisnis, oleh karena itu bahasan kurikulum hukum perusahaan haruslah lintas antar mata kuliah lain yang terkait, seperti halnya ilmu manajemen modern dan filsafat etika yang banyak membahas tentang budaya organisasi bisnis.

Di dalam literatur ilmu manajemen, pembahasan budaya perusahaan dianggap sebagai komponen kunci dari pencapaian misi dan strategi perusahaan, juga peningkatan efektivitas perusahaan dan manajemen perubahan. Budaya perusahaan menjadi hal yang penting, karena berakar dalam keyakinankeyakinan yang dipegang secara mendalam.

Oleh karena itu, budaya perusahaan dapat bekerja untuk sebuah organisasi perusahaan agar tercipta lingkungan yang kondusif demi peningkatan kinerja dan manajemen perubahan. Dalam kaitan ini, budaya perusahaan diekspresikan oleh perilaku dalam lima bidang, yakni; norma yang berupa peraturan tidak tertulis; nilai perusahaan berupa keyakinan tentang apa yang terbaik untuk organisasi perusahaan; iklim organisasi berupa suasana kerja di perusahaan yang dialami langsung oleh orang-orang di dalamnya; gaya manajemen berupa cara bagaimana para manajer berperilaku dan memberlakukan kewenangannya; dan struktur dan sistem berupa sejauh mana manajemen melakukan pendekatan birokratisnya.

Kondisi saat ini mengharuskan agar terdapat relasi yang kuat antara hukum perusahaan, budaya perusahaan 
dengan etika kewirausahaan, solusi yang dianggap paling baik adalah melalui praktik pendidikan berbasis kurikulum perubahan. Praktik ini dilakukan dengan merevitalisasi kurikulum mata kuliah hukum perusahaan. Dengan begitu, mental lulusan fakultas hukum adalah individu yang mandiri, kreatif, berintegritas pribadi, bertanggung jawab etis, berkebebasan, dan bermoral luhur. Kalau kelak memilih menjadi wirausahawan, mahasiswa akan lebih mampu melihat semangat kewirausahaan dari segi moralitas, demi tindakan baik yang ditumpukan dari pemahaman terdalam mereka atas aspek kewajiban dan tanggung jawab mandiri.

\section{Etika Kewirausahaan dan Efek}

\section{bagi Perusahaan}

Salah satu aspek yang sangat populer dan perlu mendapat perhatian dalam dunia bisnis ini adalah norma dan etika bisnis. Etika bisnis selain dapat mejamin kepercayaan dan loyalitas dari semua unsur yng berpengaruh pada perusahaan juga sangat menentukan maju atau mundurnya suatu perusahaan. ${ }^{5}$ Sedangkan menurut Leonardus Saiman, etika bisnis adalah keseluruhan dari aturan-aturan etika, baik yng tertulis yang mengatur hak-hak dan kewajiban produsen dan konsumen serta etika yang harus dipraktikkan dalam bisnis. ${ }^{6}$

Dalam pemahaman lain, etika kewirausahaan adalah suatu proses dan upaya untuk mengetahui hal-hal yang benar dan yang salah yang selanjutnya tentu melakukan hal yang benar berkenaan dengan produk, pelayanan perusahaan dengan pihak yang berkepentingan dengan tuntutan perusahaan guna mempelajari kualitas moral kebijaksanaan organisasi, konsep umum dan standar untuk perilaku moral dalam bisnis, berperilaku penuh tanggung jawab dan bermoral. Merupakan suatu kebiasaan atau budaya moral yang berkaitan dengan kegiatan bisnis suatu perusahaan.

\footnotetext{
${ }^{5}$ Anwar HM, Muhammad,. Pengantar Kewirausahaan, Teori dan Aplikasi, Prenada Media, Jakarta, 2014, hlm. 89.

${ }^{6}$ Saiman, Leonardus, Kewirausahaan, Teori, Praktik dan Kasus-Kasus, Salemba Empat, Jakarta 2012, hlm. 293.
} 
Etika untuk berbisnis secara baik dan fair dengan menegakkan hukum perusahaan dan keadilan secara konsisten dan konsekuen setia pada prinsip-prinsip kebenaran, keadaban dan bermartabat dengan mengedepankan peran etika dalam berwirausaha untuk membangun kultur bisnis yang sehat, idealnya dimulai dari perumusan etika yang akan digunakan sebagai norma perilaku sebelum aturan (hukum) perilaku dibuat dan laksanakan, atau aturan (norma) etika tersebut diwujudkan dalam bentuk aturan hukum perusahaan.

Sebagai kontrol terhadap individu, pelaku dalam bisnis yaitu melalui penerapan kebiasaan atau budaya moral atas pemahaman dan penghayatan nilai-nilai dalam prinsip moral sebagai inti kekuatan suatu perusahaan dengan mengutamakan kejujuran, bertanggung jawab, disiplin, berperilaku tanpa diskriminasi. Etika bisnis hanya bisa berperan dalam suatu komunitas moral, tidak merupakan komitmen individual saja, tetapi tercantum dalam suatu kerangka sosial, etika bisnis menjamin bergulirnya kegiatan bisnis dalam jangka panjang, tidak terfokus pada keuntungan jangka pendek saja, etika bisnis akan meningkatkan kepuasan pegawai yang merupakan stakeholders yang penting untuk diperhatikan.

Pada saat ini setiap kegiatan berwirausaha perlu beretika, sebab berwirausaha tidak hanya bertujuan untuk profit melainkan perlu mempertimbangkan nilainilai manusiawi, apabila tidak akan mengorbankan hidup banyak orang, sehingga masyarakat pun berkepentinan agar bisnis dilaksanakan secara etis, selain itu bisnis saat ini dilakukan dalam persaingan yang sangat ketat, maka dalam persaingan bisnis tersebut, orang yang bersaing dengan tetap memperhatikan norma-norma etis pada iklim yang semakin profesional justru akan menang.

Keutamaan yang harus menandai pebisnis perorangan bisa disebut kejujuran, fairness, kepercayaan dan keuletan. Keempat keutamaan ini berkaitan erat satu sama lain dan kadangkadang malah ada tumpang tindih di antaranya. Fairness, kesediaan 
untuk memberikan apa yang wajar kepada semua orang dan dengan wajar dimaksudkan apa yang bisa disetujui oleh semua pihak yang terlibat dalam suatu transaksi.

Keutamaan-keutamaan yang dimilliki manajer dan karyawan sejauh mereka mewakili perusahaan, adalah keramahan, loyalitas, kehormatan dan rasa malu. Keramahan merupakan inti kehidupan bisnis, keramahan itu hakiki untuk setiap hubungan antar manusia, hubungan bisnis tidak terkecuali.

Loyalitas berarti bahwa karyawan tidak bekerja sematamata untuk mendapat gaji, tetapi mempunyai juga komitmen yang tulus dengan perusahaan. Kehormatan adalah keutamaan yang membuat karyawan menjadi peka terhadap suka dan duka serta sukses dan kegagalan perusahaan dan rasa malu membuat karyawan solider dengan kesalahan perusahaan.

\section{PENUTUP}

\section{Kesimpulan}

Kurikulum hukum perusahaan harus dipersiapkan untuk masuk ke dunia industri dengan bercirikan dan berkarakter khas, dan hukum perusahaan ini tidak lepas dari kondisi budaya bisnis eksternal yang berkembang. Hal ini berarti, kondisi budaya eksternal diandaikan sudah tertanam terlebih dahulu di dalam diri mahasiswa, sebelum mereka ini bekerja di sebuah perusahaan dan kemudian hanyut di dalam budaya perusahaan itu. Sebab implikasinya, membangun paradigma baru kurikulum menjadi suatu kewajiban mutlak yang harus dipenuhi oeh fakultas hukum saat ini.

Oleh karena itu, kurikulum hukum perusahaan di perguruan tinggi harus menyelaraskan diri dengan gaya manajemen perubahan yang terjadi dan berkembang saat ini. Dalam penegasan lain, semangat kapitalisme yang amat merasuki dunia pendidikan tinggi dewasa ini, menyebabkan mahasiswa hanya tumbuh sebagai makhluk industri, dan mereka sama sekali tidak bisa merasakan spirit pendidikan dengan kurikulum perubahan di dalam hukum perusahaan. Dalam menyikapi derasnya budaya perusahaan yang 
kapitalistik, dalam rangka menumbuhkan semangat kewirausahaan yang bercirikan khas Indonesia harus melalui kurikulum hukum perusahaan yang kontekstual untuk dewasa ini.

\section{Saran}

Menyadari posisi strategis tersebut, revitalisasi dalam membangun paradigma baru hukum perusahaan harus segera dilakukan. Dimana dalam era pasar bebas saat ini banyak pelaku bisnis menjalankan usaha tanpa pemahaman hukum perusahaan dan budaya perusahaan yang kuat. Implikasi dari hal ini, teori-teori hukum perusahaan, dalam kurikulum perkuliahan, juga bagus untuk ditinjau kembali.

Pasalnya, bagaimana kita menumbuhkan etika dan semangat kewirausahaan di kalangan mahasiswa kita, sementara kurikulum hukum perusahaan dan kewirausahaan hanya memuat dengan teori-teori yang jelas-jelas dibumbui oleh semangat kapitalisme modern.

\section{E. DAFTAR PUSTAKA}

Anwar HM, Muhammad. 2014. Pengantar Kewirausahaan, Teori dan Aplikasi. Prenada Media. Jakarta.

Barnadib, Imam. 2002. Filsafat Pendidikan. Adicita. Yogyakarta.

Depdiknas. 2003. Undang-Undang Sistem Pendidikan Nasional. Badan Penelitian dan Pengembangan Depdiknas. Jakarta.

Hall, Edward T. \& William Foote Whyte. 1998. "Komunikasi Antarbudaya: Suatu Tinjauan Antropologis, dalam Komunikasi Antarbudaya, Panduan Berkomunikasi dengan Orang-orang Berbeda Budaya (editor: Deddy Mulyana \& Jalaluddin Rakhmat). Remaja Rosdakarya. Bandung.

Ibrahim, Johnny. 2006. Teori dan Metodologi Penelitian Hukum Normatif. Bayumedia Publishing. Malang.

Mulhadi. 2010. Hukum Perusahaan, Bentuk-Bentuk Badan usaha di Indonesia, Bogor: Ghalia Indonesia.

Magnis Suseno. 1987. Masalah-masalah Pokok Filsafat Moral. Kanisius. Yogyakarta.

Mangunhardjana, A. 1997. Isme-isme dalam Etika: dari A Sampai $Z$. Yogyakarta: Kanisius.

Rasyid Saliman, Abdul, 2017. Hukum Bisnis untuk Perusahaan, cetakan ke 11, Jakarta: Prenada Media.

Rasjidi, Lili dan Rasjidi, Liza Sonia, 2005, Pengantar Metode Penelitian dan Penulisan Karya 
Ilmiah Hukum, Bandung: FHUNPAD.

Saiman, Leonardus. 2012. Kewirausahaan, Teori, Praktik dan Kasus-Kasus. Salemba Empat. Jakarta.

Suriasumantri Jujun S. 1996. Ilmu dalam Perspektif Moral, Sosial, dan Politik: Sebuah Dialog tentang Dunia Keilmuan Dewasa ini. Gramedia. Jakarta.

2005. Filsafat Ilmu: Sebuah Pengantar Populer. Sinar Harapan. Jakarta.

Wibowo, Wahyu. 2003. Sihir Iklan: Format Komunikasi Mondial dalam Kehidupan UrbanKosmopolit. Gramedia. Jakarta. 